\title{
The Effect of Acceptable Complementary Food with Dadih Toward Nutritional Status of Children Aged 12-24 Months
}

\author{
Helmizar $^{1}$, Inova Gusmelia ${ }^{2}$, Rani Wahyuni ${ }^{3}$, Putri Aulia Arza $^{4}$ \\ \{eelbiomed@gmail.com ${ }^{1}$, vaadandelion@gmail.com², \\ raniwahyuni09@gmail.com ${ }^{3}$, tilla.arza@gmail.com $\left.{ }^{4}\right\}$ \\ ${ }^{1-4}$ Department of Public Health Nutrition, Faculty of Public Health Andalas University, Padang, \\ Indonesia
}

\begin{abstract}
Stunting or chronic malnutrition is the result of poor nutrition and poor health in early children under five. The purpose of this study is to create an acceptable complementary food Dadih and its effect on changes in consumption of nutritional status children aged 1224months. This type of research applied quasi-experimental studies in the Intervention Group and control group. The results of the measurement of product acceptability showed that the children in the Intervention Group consumed $54.54 \%$ of biscuits. The nutritional status of children, using the Z-score on weight for height index (WHZ), in the Intervention Group was $0.53 \mathrm{SD}$, and the Control Group was $-0.86 \mathrm{SD}$. The complementary food Dadih is good enough to improve the nutritional status of children aged 12-24 months. It can be applied to children in Agam Regency.
\end{abstract}

Keywords: Acceptable, Local Complementary Food, Dadih, nutritional status of children

\section{Introduction}

Nutrition problems in children under five are still a major problem in Indonesia. It can be seen in poor nutrition, short and slim in infants in various regions [1]. Based on the Global Nutrition Report (2014), Indonesia raises the problem of malnutrition due to malnutrition. It can be seen from the growth of children in the form of short stature (stunting) or high stature (wasting) [2]. In addition, babies are susceptible to diseases, especially to infections, and their level of intelligence tends to be lower [3].

West Sumatra becomes one of the contributors to the high wasting, stunting, and underweight numbers in toddlers. Data from the West Sumatra Provincial Health Office shows that the underfives are very thin in $2017(10,1 \%)$, which is an increase from the previous year of $8,9 \%$. The prevalence of stunting toddlers (short and very short) increased by $5 \%$ that is $25,6 \%$ (2016) to $30.6 \%$ (2017). The same thing with toddlers with severe malnutrition increased from $16 \%$ (2016) to $17,5 \%$ (2017) [4] 
Based on data from the West Sumatra Provincial Health Office in 2017, Agam became the 7th highest regency to have wasting toddlers. While in 2016, it amounted to $7,1 \%$ to $9,8 \%$ in 2017 . The same thing with stunting toddlers, in 2016 amounted to $22,1 \%$ and increased in the next year 2017 amounted to $31,3 \%$ of toddlers. Likewise, malnutrition toddlers also increased by $10,6 \%$ in 2016 and by $15,4 \%$ in 2017 [4]

The selection of local material products is needed to yield the potential of Minangkabau local wisdom in West Sumatra. It also has the potential to improve the economy of the community. Hence, by providing indirect intervention, the community can make itself even as an economic source. Therefore, besides improving the nutritional status of children, it also can improve the family's economy.

Initial data collection had been carried out regarding the nutritional status of the children under two years at the Biaro Health Center. The results of the mass weighing in February 2019 found that 777 children aged two years $1 / 3$ (215 children) experienced undernourishment, wasting, and stunting.the mothers had been intervened by previous researches [5]. The current study intends to intervene in the role of MP-ASI local with Dadih in the form of biscuits with vla Dadih and observe the effectiveness of interventions. It also provides the acceptance of the local MP-ASI with Dadih on the nutritional status of children aged 12-24 months at Biaro Health Center coverage in Agam Regency in 2019.

\section{Method}

This study was designed into several stages, including; 1) optimization of the formula for making complementary food rich in Dadih; 2) chemical analysis (nutrition), microbiology (lactic acid bacteria), and organoleptic tests; 3 ) producing complimentary food (biscuits) with Dadih as a pilot plan and product packaging design; 4) product test to stunting children.

The product of this study was biscuits as complimentary food rich in Dadih. The biscuits had been mixed to meet the standard nutritional requirements of complementary food for children. Global Consultation Report (World Health Organization) states that the MP-ASI for children aged $12-24$ months is $550 \mathrm{kcal}$ per day. It is because breast milk itself not enough to meet the energy and nutrient need for children's growth and development.

After the product processed and the compositions have met the nutritional value, then the organoleptic tests are performed. There are three compositions used in this organoleptic test; formula $\mathrm{A}, \mathrm{B}$, and $\mathrm{C}$. The tests include smoothness test, swallowing test, adhesiveness test, color test, aroma test, and taste. The process of making curd biscuit and organoleptic tests will be carried out at the Nutrition Laboratory, Faculty of Public Health, Andalas University.

The food products were distributed to the children under five in the working area of the Regency of Agam, West Sumatra. The acceptance of complementary food is done using a quasi-experimental with a pre-test and post-test on control group design. The subjects are children aged 12-24 monthsthe total sample of 22 from Intervention Group dan 22 from Control Group. The respondents are grouped into the control group (provided biscuits without Dadih) and the experimental group (provided biscuits with Dadih). The data are analyzed based on paired sample t-test. 


\section{Result}

The complementary food formula used in the current study are made from local food raw material: corn flour, red bean flour, and soybeans flour called the $F-J K K$ formula. The formula has passed several tests to measure the nutritional value, such as carbohydrates, fat content, protein content, water content, and ash content, which states that the formula for complementary food is good for consumption. This complimentary food formula was further developed into biscuits enriched with Dadih (the result of buffalo milk fermentation traditionally with bamboo).

The complementary food form of biscuits provided consisted of formula made from corn flour, soybean flour, and reb bean flour, with the eggs, butter, and sugar. Whereas the Vla Dadih is made from cornstarch, liquid milk, butter, granulated, sugar, and Dadih.one portion of biscuits in 1 day is 6 pieces (72gr) with 22 grams of vla Dadih, which contains $495 \mathrm{kcal}$ of energy, 15.7 grams of proteins, 32.6grams of fat, and 57,6 grams of carbohydrate. These biscuits provide additional energy of $44 \%$ and $60,4 \%$ protein from the nutritional needs of children aged $12-24$ months.
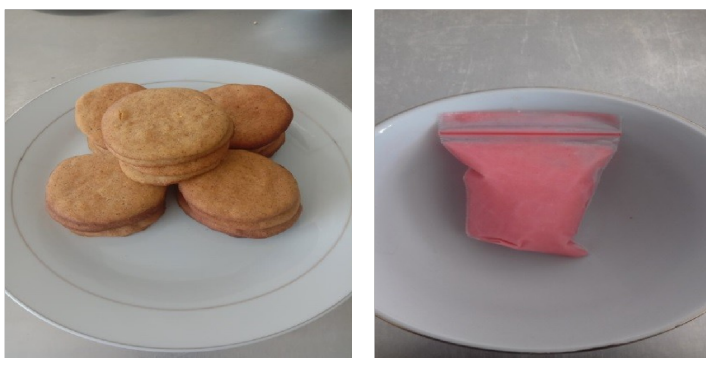

Fig.1.Type of intervention form of biscuits and Vla enriched with Dadih as a complementary food for children

The number of local MP-ASI has enriched during the four weeks of the intervention, which is recorded using a Comstock scale visual estimate from that is monitored once a week. The number of local MP-ASI consumed by respondents every week can be seen in the table below.

Table 1. Average Amount of Local MP_ASI with Dadih

\begin{tabular}{cccr}
\hline Intervention & \multirow{2}{*}{ Mean \pm SD } & Median & Min-Max \\
\hline Week 1 & $48,80 \pm 27,21$ & 42,24 & $11,32-100$ \\
Week 2 & $58,16 \pm 29,84$ & 58,38 & $12,44-100$ \\
Week 3 & $57,81 \pm 26,52$ & 54,24 & $0,00-100$ \\
Week 4 & $58,80 \pm 25,40$ & 56,74 & $17,29-100$ \\
\hline
\end{tabular}


Table 1. indicates that the total MP-ASI consumed by respondents during the intervention was $55,89 \%$. In the first week, the average MP-ASI consumed is $48,80 \%$, the second week increased to $58,16 \%$, and decreased in the third week to $57,81 \%$ and in the fourth week amounted to $58,80 \%$.

\section{Discussion}

\subsection{Acceptability}

The complementary food for children under two years can be seen from the child's acceptance of the food provided or can be seen from the amount of food that has been consumed. The acceptability of food represents the ability of a person in the food served, and following their needs here. The acceptance is traced by using the visual Comstock estimation method [6].

The result shows the experimental group that the acceptance rate is below reaching $75 \%$ of children every week.

The low acceptance of biscuits is due to several factors, including sick children and habits of children and siblings, to consume candy. These situations prevent children from consuming biscuits.

This is the line with Iskandar's study in 2017 in which the initial reception of formulas was not so good due to an appetite disorder before the intervention, and the mothers still did not cooperate to support supplementary feeding, so that if the toddler did not want to consume the formula given [7]. The same thing in this study can be seen from the child's acceptance of low biscuits, in the first week only $48,8 \%$. It is due to some findings in the field. Children with fever and cold will have a lower appetite.

Abeng's research in 2014 stated that infectious diseases affect appetite, which will affect body weight. The emergence of malnutrition is not only due to lack of food but also because of disease. Children who get enough food may get diarrhea or fever, which leads to malnutrition [8]. Likewise, in children who do not eat well enough, their immune system can be weak. In such circumstances, susceptible to infection can reduce appetite, and ultimately can suffer from malnutrition.

\subsection{The difference in Mean Nutrition Status of Children Before and After Intervention in the Intervention and Control Groups}

Based on this study, the nutritional status of children in each group is known, both the experimental and Control Groups. The mean nutritional status of children in the experimental Group, based on Z-score HAZ index of $-2.09 \mathrm{SD}$ to $-2.07 \mathrm{SD}$. Based on WHO index of $-0.87 \mathrm{SD}$ to -0.53 $\mathrm{SD}$ and based on WAZ index of $-1.71 \mathrm{SD}$ to $-1.47 \mathrm{SD}$. While in the Control Group based on the HAZ index of $-2.39 \mathrm{SD}$ to $-2.32 \mathrm{SD}$, based on WHO index of $-1.05 \mathrm{SD}$ to $-0.84 \mathrm{SD}$ and based on WAOindex of -1.84 to -1.79 SD.

It can be seen through the improvement of nutritional status based on Z-score HAZ, WHZ, and WAZ in the experimental group. This relates to Iskandar's study on the contribution of supplementary food modification to the nutritional status of toddlers for four weeks, which can increase the average Z-score before being given a formula based on the WAZ index is $-2.71 \mathrm{SD}$ to $-2.49 \mathrm{SD}[7]$. 
The result of the statistical test indicates no significant difference between nutritional status before the intervention and after the intervention. ( $\mathrm{p}>0.05)$. This condition can be caused by the research time is shortly by only looking at the effect of giving MP-ASI with Dadih for four weeks. So the effect of giving a significant nutritional status.

According to Fauzi Arasj's research (2014) on the effect of giving Dadih through supplementary food on nutritional status, the incidence of diarrhea and stunted children aged 1-4 years for 90 days giving a significant impact on HAZ and WHZ indices, where there is a change in the Z-score HAZ index from $-2.269 \pm 0.57$ to $-1.665 \pm 0.55$. The WHZ index also shows the change in $\mathrm{Z}$-score from $-1.665 \pm 0.55$ to $-0.740 \pm 0.81$ [9].

Associated with the study of Imas Rini et al. in 2017, the supplementary feeding on the nutritional status of malnourished children under three months gave a change following the WAZ and WHZ index. Obtained changes in the WHZ index is 0.69 SD, and WAZ index 0.62 SD [10]. The sensitivity of WAZ can cause changes that occur is relatively higher for sudden small changes that can be the result of weight measurement, while the WHZ indicator has a lower level of sensitivity to nutritional deficiencies in the short term.

\section{Conclusion}

The result indicates improvement after the intervention. Before the intervention, calories of $803.10 \mathrm{kcal}$ met $71.38 \%$ of the needs of children based on the Indonesian Recommended Dietary Allowances (RDA). After the intervention, it increases to $1.115 \mathrm{kcal}$, which met $99.10 \%$ of the needs of children based on the RDA.

The nutritional status of children based on the Z-score, the HAZ, WHZ, and WAZ index, during the intervention also increased. Based on the HAZ index, there is a difference of mean 0.02, WHZ index difference is 0.34 , and WAZ is 0.24 .

\section{References}

[1] Datesfordate AH, Kundre R, Rottie JV. Hubungan Pemberian Makanan Pendamping Air Susu Ibu (MPASI) Dengan Status Gizi Bayi Pada Usia 6-12 Bulan Di Wilayah Kerja Puskesmas Bahu Manado. Jurnal Keperawatan 2017;5(2).

[2] Haddad, L., Achadi, E., Bendech, M. A., Ahuja, A., Bhatia, K., Bhutta, Z., ... \& Eriksen, K. (2015). The Global Nutrition Report 2014: actions and accountability to accelerate the world's progress on nutrition. The Journal of nutrition, 145(4), 663-671.

[3] Khasanah DP, Hadi H, Paramashanti BA. Waktu Pemberian Makanan Pendamping ASI (MP-ASI) Berhubungan Dengan Kejadian Stunting Anak Usia 6-23 Bulan Di Kecamatan Sedayu. Jurnal Gizi Dan Dietetik Indonesia. 2016;4(2).

[4] Dinas Kesehatan Kota Padang. Laporan Tahunan 2015, 2016, 2017. Padang: Dinas Kesehatan Kota Padang; 2015 
[5] Helmizar. Dadih and Zinc Supplementation during Pregnancy Benefits Pregnancy Outcomes and Humoral Immune Response in West Sumatera, Indonesia.. Abstarct of the Asian Congress of Nutrition 2019. Annals of Nutrition \& Metablism. 75/Suppl 3/1-424 (2019)

[6] Putri SS, Jumirah, Lubis Z. Karakteristik Dan Daya Terima Bubuk Instan Campuran Tepung Kecambah Jagung, Tepung Tempe, Dan Tepung Wortel Sebagai Makanan Pendamping ASI. Jurnal Gizi, Kesehatan Reproduksi dan Epidemiologi. 2016;1(2).

[7] Iskandar. Pengaruh Pemberian Makanan Tambahan Modifikasi Terhadap Status Gizi Balita. Jurnal AcTion: Aceh Nutrition Journal. 2017;2(2).

[8] Abeng, A. T., Ismail, D., \& Huriyati, E. (2014). Sanitasi, infeksi, dan status gizi anak balita di Kecamatan Tenggarong Kabupaten Kutai Kartanegara. Jurnal Gizi Klinik Indonesia, 10(3), 159-168.

[9] Arasj F. Pengaruh Pemberian Dadih (Susu Kerbau Terfermentasi) Melalui Makanan Tambahan Terhadap Status Gizi, Kejadian Diare Dan Ispa Anak Pendek (Stunted) Usia 1-4 Tahun, Studi Dilakukan Di Kenagarian Kototangah, Kecematan Tilatang Kamang. Jurnal AFIYAH. 2014;1(1). 